\title{
Combined Effects of Curing Temperatures and Alkaline Concrete on Tensile Properties of GFRP Bars
}

\author{
Wen-rui Yang, ${ }^{1}$ Xiong-jun He, ${ }^{1}$ Kai Zhang, ${ }^{2}$ Yang Yang, ${ }^{1}$ and Li Dai ${ }^{1}$ \\ ${ }^{1}$ School of Transportation, Wuhan University of Technology, Wuhan 430063, China \\ ${ }^{2}$ Department of Road and Material, Jiangxi Transportation Institute, Nanchang 330025, China \\ Correspondence should be addressed to Xiong-jun He; hxjwhut@163.com
}

Received 13 October 2016; Revised 29 November 2016; Accepted 20 December 2016; Published 19 January 2017

Academic Editor: Ulrich Maschke

Copyright (c) 2017 Wen-rui Yang et al. This is an open access article distributed under the Creative Commons Attribution License, which permits unrestricted use, distribution, and reproduction in any medium, provided the original work is properly cited.

\begin{abstract}
A significant number of studies have been conducted on the tensile properties of GFRP bars embedded in concrete under different environments. However, most of these studies have been experimentally based on the environmental immersion test after standardcuring and the lack of influence on the tensile properties of GFRP bars embedded in concrete during the curing process of concrete. This paper presents the results of the microscopic structures through scanning electron microscopy (SEM), Fourier transform infrared spectroscopy (FTIR), differential scanning calorimetry (DSC), and tensile properties of GFRP bars, which were employed to investigate the combined effects of curing temperatures and alkaline concrete on tensile properties of GFRP bars. The results showed that the higher curing temperature aggravated the influence of the alkaline concrete environment on GFRP bars but did not change the mechanisms of mechanical degradation of the GFRP bars. The influence of different curing temperatures on the tensile strength of GFRP bars was different between the bare bar and bars in concrete. Finally, the exponential correlation equation of two different test methods was established, and the attenuation ratio of the tensile strength of GFRP bars embedded in concrete under different curing temperatures was predicted by the bare test.
\end{abstract}

\section{Introduction}

Decades of researches and practical applications have proved that the use of GFRP bars embedded in concrete has been an effective method to solve the reinforce corrosion in concrete structures [1-8]. A number of investigations have been conducted to evaluate the effects of temperature, moisture, chemical erosion, loading, and different harsh environments on the properties of GFRP bars. These studies indicated that the influence of GFRP bars in alkaline environment was more obvious especially under the same load. He et al. [6-8] explored the long-term tensile strength and flexural behavior of GFRP bars embedded in concrete beams with initial cracks. The experimental results showed that the beams with crack will accelerate the degradation of the flexural properties, shear properties, and tensile strength of GFRP bars. The durability of GFRP bars will be significantly affected under high temperature and humidity $[9,10]$.

Many researchers revealed that the alkaline concrete will increase the additional stress, surface crack, and porosity under the steam-curing of high temperature and humidity [11-15]. Therefore, the influence of the curing system on GFRP bars embedded in concrete cannot be neglected. The lack of investigations about the effect of different curing systems on the performance of GFRP bars embedded in concrete is a vital problem.

In order to evaluate combined effects of curing temperatures and alkaline concrete tensile properties of GFRP bars, the scanning electron microscopy (SEM), Fourier transform infrared spectroscopy (FTIR), differential scanning calorimetry (DSC), and pull-out test of GFRP bars have been conducted. Based on the test data, the exponential correlation equation was established to provide a theoretical basis for the tensile property design of GFRP bars under different curing systems.

\section{Experimental}

Sun et al. [16] revealed that the performance degradation of GFRP bars embedded in concrete was significantly lower 


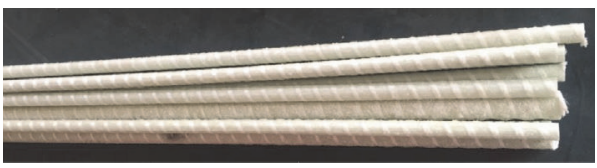

(a) GFRP bare bars

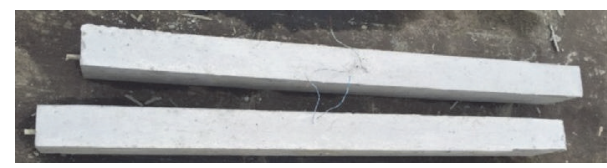

(b) GFRP bars embedded in concrete beams

Figure 1: Specimens.

TABLE 1: Test specimens.

\begin{tabular}{|c|c|c|c|}
\hline Environment & Curing system & Curing temperature & Working condition \\
\hline \multirow{5}{*}{ GFRP bare bars } & Reference & - & $\mathrm{RE}$ \\
\hline & \multirow{2}{*}{ Standard-curing } & $20^{\circ} \mathrm{C}$ & B-Sta \\
\hline & & $40^{\circ} \mathrm{C}$ & B-Ste 40 \\
\hline & \multirow{2}{*}{ Steam-curing } & $60^{\circ} \mathrm{C}$ & B-Ste60 \\
\hline & & $80^{\circ} \mathrm{C}$ & B-Ste 80 \\
\hline \multirow{4}{*}{ GFRP bars embedded in concrete } & \multirow{2}{*}{ Standard-curing } & $20^{\circ} \mathrm{C}$ & C-Sta \\
\hline & & $40^{\circ} \mathrm{C}$ & C-Ste 40 \\
\hline & \multirow{2}{*}{ Steam-curing } & $60^{\circ} \mathrm{C}$ & C-Ste60 \\
\hline & & $80^{\circ} \mathrm{C}$ & C-Ste 80 \\
\hline
\end{tabular}

than that of GFRP bars conditioned in an alkaline solution. The practical application and experimental studies showed that the traditional accelerated test results cannot reflect the long-term performance of FRP in concrete [17]. In ACI440.1R-15, it points out that the relationships between data on bare bars and data on bars embedded in concrete are affected by additional variables, such as the degree of protection offered to the bars by the concrete [18]. These reports indicated that the data on GFRP bars embedded in concrete were more accurate in the prediction and design guidance of GFRP bars reinforced concrete. The exponential correlation equation of two different test methods is established to extend previous researches and provide a more reliable basis for the tensile properties degradation of GFRP bars. Therefore, the specimens used in experiments included GFRP bars embedded in concrete and the GFRP bare bars to highlight the influence of alkaline concrete on the tensile properties of GFRP bars.

\subsection{Materials}

2.1.1. GFRP Bars. The GFRP bars used in the study were provided by Fenghui Composite Materials Co., Ltd., Nanjing, China. This type of bars is made up of unidirectional roving of E-glass and epoxy vinyl ester resin. The bars appear as milky spiral sandblasting, and each screw is $14 \mathrm{~mm}$ in length and $0.325 \mathrm{~mm}$ in height.

2.1.2. Specimen Preparation. The specimens used in experiments included GFRP bars embedded in concrete beams and the GFRP bare bars (Figure 1). The concrete beams were cast in accordance with typical concrete mix design procedures with a cure time of 28 days to obtain a target strength of $42.5 \mathrm{MPa}[19,20]$. The concrete was provided by a local ready-mix plant and had a water-to-cement ratio of 0.59 . The GFRP reinforced concrete beams specimens were rectangular plain concrete beams with a length of $1100 \mathrm{~mm}$, width of $80 \mathrm{~mm}$, and depth of $110 \mathrm{~mm}$, with a single longitudinal GFRP bar centered at $30 \mathrm{~mm}$ from the bottom of the section.

2.2. Curing Systems. Two types of curing systems for GFRP bare bars and GFRP bars embedded in concrete beams were used in this study: (1) for standard-curing system, the specimens were treated under a standard-curing with the temperature of $(20 \pm 5)^{\circ} \mathrm{C}$; subsequently, the specimens were conditioned with a temperature of $(20 \pm 2)^{\circ} \mathrm{C}$ and a relative humidity more than $95 \%$ for $28 \mathrm{~d}$, and (2) steamcuring system, in which the concrete is exposed to elevated temperature, shows an accelerated hydration and nonuniform distribution of hydration products resulting in a rapid increase of the compressive strength in early age. The faster hardening and the changes of porosity may be more obvious when the temperature is higher. The temperatures of steamcuring are $40^{\circ} \mathrm{C}, 60^{\circ} \mathrm{C}$, and $80^{\circ} \mathrm{C}$, respectively, with the treatment duration of $8 \mathrm{~h}$. The heating rate and cooling rate are controlled as $10^{\circ} \mathrm{C} / \mathrm{h}$ [21]. After the process of steamcuring, the specimens were placed in the standard-curing room for 28 . The related parameters of the specimens are shown in Table 1.

\subsection{Method}

2.3.1. Tensile Test. All tensile specimens were tested under tension according to ACI 440.3R-04 [22]. Tensile specimen for testing was prepared by anchoring two ends of the bar in steel plugs filled with epoxy resin. The free length between the steel plugs was about $300 \mathrm{~mm}$ to ensure the anchor bonding strength is higher than the tensile stress according to the guidelines as specified in ACI 440.3R-04 [22]. The test was carried out with a universal testing machine (SHT4106-G) and an extensometer of $50 \mathrm{~mm}$ gauge length was mounted with clips at the center of test specimen. The applied load 
TABLE 2: Tensile test results of GFRP bars.

\begin{tabular}{|c|c|c|c|c|c|}
\hline \multirow[b]{2}{*}{ Environment } & \multirow[b]{2}{*}{ Curing system } & \multirow[b]{2}{*}{ Working condition } & \multicolumn{3}{|c|}{ Ultimate tensile strength (UTS) } \\
\hline & & & $\begin{array}{l}\text { Average } \\
(\mathrm{MPa})\end{array}$ & $\begin{array}{c}\text { Tensile strength retention } \\
(\%)\end{array}$ & $\begin{array}{l}\text { Variable coefficient } \\
\qquad \%)\end{array}$ \\
\hline \multirow{5}{*}{ GFRP bare bars } & Reference & $\mathrm{RE}$ & 1320 & 100 & 1.67 \\
\hline & \multirow{2}{*}{ Standard-curing } & B-Sta & 1300 & 98 & 2.48 \\
\hline & & B- Ste 40 & 1271 & 96.3 & 3.31 \\
\hline & \multirow{2}{*}{ Steam-curing } & B-Ste60 & 1214 & 92 & 5.11 \\
\hline & & B-Ste80 & 1122 & 85 & 3.69 \\
\hline \multirow{4}{*}{$\begin{array}{l}\text { GFRP bars embedded } \\
\text { in concrete }\end{array}$} & \multirow{2}{*}{ Standard-curing } & C-Sta & 1287 & 97.5 & 2.67 \\
\hline & & C-Ste 40 & 1273 & 96.42 & 3.28 \\
\hline & \multirow{2}{*}{ Steam-curing } & C-Ste60 & 1252 & 94.85 & 3.57 \\
\hline & & C-Ste80 & 1192 & 90.34 & 2.96 \\
\hline
\end{tabular}

was recorded during the test with a data-acquisition system monitored by a computer.

2.3.2. Microstructural Observations. Scanning electron microscopy (SEM) observations and image analysis were performed to examine the microstructure of specimens in steamcuring with $60^{\circ} \mathrm{C}$. All specimens were first cut, polished, and coated with a thin layer of gold palladium by a vapor deposition process. Once the surfaces were coated, the transversal and longitudinal surfaces were examined using a JSM-5610LV SEM. Before the observation, the surface of the specimen should be cleaned to avoid the influence of the surface residue.

2.3.3. Differential Scanning Calorimetry (DSC). Differential scanning calorimetry (DSC) can be used to characterize information on the thermal behavior and characteristics of polymer materials and composites. The glass transition temperature $\left(T_{g}\right)$ is one of the key parameters in analyzing the durability behavior of GFRP bars. Specimens weighing 10$13 \mathrm{mg}$ were cut from unconditioned GFRP bars, GFRP bars embedded in standard-curing concrete and steam-curing concrete. Subsequently, they were analyzed using a PYRIS1 differential scanning calorimeter (DSC).

2.3.4. Fourier Transform Infrared Spectroscopy (FTIR). FTIR spectra were recorded using a Nicolet 6700 spectrometer equipped with an attenuated total reflectance (ATR) device. Fourier transform infrared spectroscopy (FTIR) analysis of GFRP bars embedded in standard-curing concrete and steam-curing concrete were conducted to determine if hydrolysis reactions occurred in the polymer resin, which can lead to an important loss of mechanical properties.

\section{Results and Discussion}

3.1. Tensile Strength Retention of GFRP Bars. Some researchers $[4,6]$ found that the tensile strength of the GFRP bar was not only related to its diameter, but also had a great relationship with the environmental factors, such as temperature, humidity, and alkaline solution. The degeneration of GFRP bars tensile strength is a function of the relevant time during long-term service process, which is mainly due to the presence of moisture or corrosion solution leading to corrosion of glass fiber as well as the corrosion rate increases with temperature increase [23]. In the same external environment, the corrosion rate will increase with time. When GFRP bars are in a humid environment, water diffuses into the polymer matrix and even reaches the glass fibers by the matrix to reduce the tensile strength [24]. It can be seen that the difficulty from the external media into the GFRP bar and the variation of tensile properties of the GFRP bar are different under different temperature curing systems.

Table 2 shows the degradation of the tensile strength of GFRP bars under different curing systems. Table 2 indicates that the tensile strength of GFRP bars embedded in concrete is lower than that of GFRP bare bars under standard-curing system, which can prove that the strong alkaline concrete has impact on GFRP bars. However, the tensile strength retention of GFRP bars embedded in steam-curing concrete is $97.5 \%$ of that of GFRP bars in the standard-curing concrete, and the minor damage is mainly due to the lower temperature of standard-curing environment and shorter curing period $(28 \mathrm{~d})$. Therefore, the effect on the tensile strength degradation of GFRP bars is relatively insignificant, which is consistent with the conclusion that the degradation of GFRP bars does not appear by the Canada A Mufti research team's study for a period of 5 years to 8 years [25].

The degradation of tensile strength of GFRP bars embedded in steam-curing concrete is significantly lower than that of GFRP bars embedded in standard-curing concrete, and the tensile strength retention ratio declines with the rise of curing temperature. But the difference is very small between standard-curing system and steam-curing system, which is mainly due to the steam-curing age of 28 days leading to relatively small impact on GFRP bars. If the steam-curing time is extended or the steam-curing temperature is elevated, the deterioration degree of tensile strength of GFRP bars will increase. Therefore, it is necessary to study the influence of curing temperature and curing period on the performance of GFRP bars.

The variation of tensile strength of GFRP bare bars and GFRP bars embedded in concrete is different with different curing temperatures. It did not demonstrate a consistent 


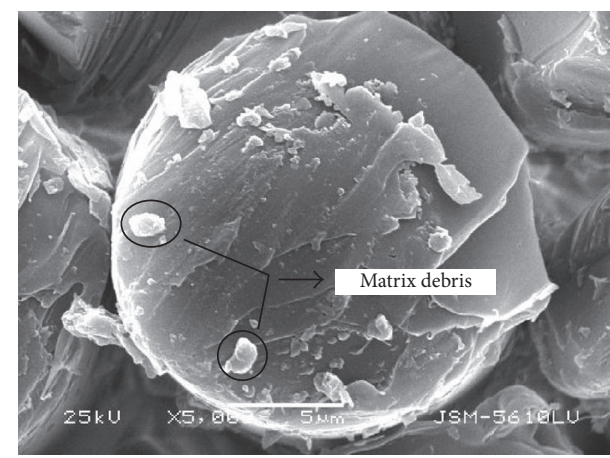

(a) Transverse section $\times 5000$

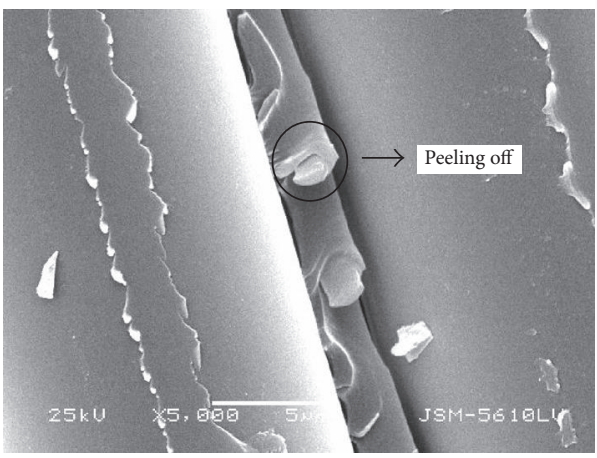

(c) Longitudinal section $\times 5000$

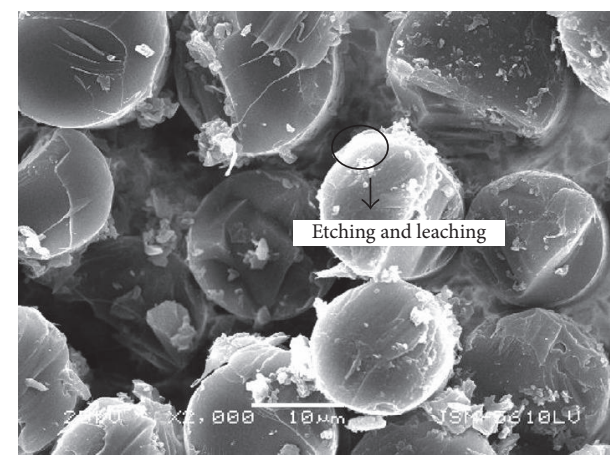

(b) Transverse section $\times 2000$

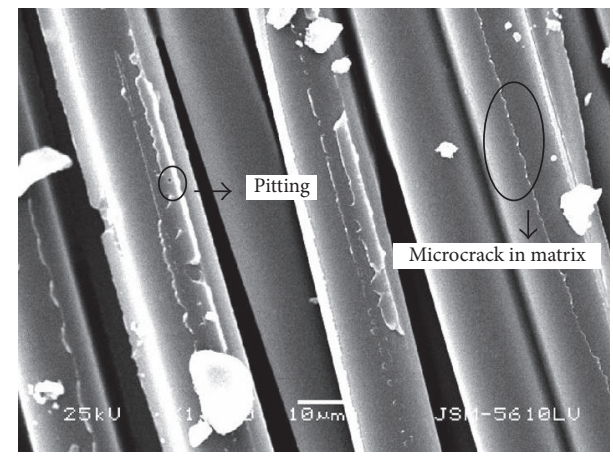

(d) Longitudinal section $\times 1000$

FIGURE 2: Microstructure morphology of GFRP bars in the standard-curing environment.

change trend in Table 2. The tensile strength retention of GFRP bare bars is higher than the GFRP bars embedded in concrete with the lower curing temperature (below $40^{\circ} \mathrm{C}$ ). The effects of high curing temperature and alkaline concrete on GFRP bare bars are gradually significant. The deterioration degree of GFRP bare bars is higher than which were embedded in concrete with the increase of curing temperature. It is necessary to analyze the correlation of two test methods for the design of GFRP bars embedded in concrete because the variation of tensile properties of GFRP bars is not the same as the GFRP bars embedded in concrete.

3.2. Microanalysis of GFRP Bars. Figures 2 and 3 illustrate the effect of the micromorphology of GFRP bare bars and GFRP bars embedded in concrete with the standard-curing. Figures 3(a) and 3(b) show that the transverse section of GFRP bars is loose, and the longitudinal section of GFRP bars presents scattered fragments of resin as shown in Figures 3(c) and 3(d). The same phenomenon existed for the GFRP bare bars, but the transverse and longitudinal of fibers are relatively smooth. It is obvious that the damage degree of GFRP bars embedded in concrete is greater than the GFRP bare bars with standardcuring system. The main reason is that alkali ions destroy the backbone of glass molecules by breaking the Si-O-Si network to form dissolvable products. The reaction between the glass fiber and alkali will lead to degradation of the mechanical properties of glass fiber and hence to reduction in the fracture properties of the GFRP bars embedded in concrete beams.
Figure 5 shows that the steam-curing system with $60^{\circ} \mathrm{C}$ temperature aggravates the influence of the alkaline concrete environment on GFRP bars. However, the curing temperature $\left(60^{\circ} \mathrm{C}\right)$ certainly has the impact on degradation of GFRP bars compared with Figures 2 and 4 . Figures 4 and 5 show that there is no significant difference between GFRP bare bars and GFRP bars embedded in concrete under steam-curing system.

3.3. Glass Transition Temperature. Glass fibers are the most susceptible to degradation without the absence of moisture and alkalinity [13]. The reaction of GFRP composite with the alkali in concrete is a major durability concern. Typically, steam-curing concrete environments have high alkalinity [12]. Sun et al. [16] reported that glass fibers were known to degrade in the presence of water, and the moisture can decrease the glass transition temperature $\left(T_{g}\right)$ of the resin, which potentially had a significant effect on the tensile strength of GFRP bars. High temperature environment will make the GFRP bar of the resin and glass fiber soft as well as cause a weakening or even loss of bond performance between the two, leading to a decline in tensile properties of GFRP bars.

Table 3 presents the glass transition temperature $\left(T_{g}\right)$ for the first and second heating scans of GFRP bars. The $T_{g}$ values of the second scan for all tested samples are higher than of the first scan. This result illustrates that the GFRP bars were not completely cured, as postcure reactions were shown in the process of the second heating scan. Compared with $\mathrm{RE}$ specimens, the cure ratio of C-Sta specimens decreases 


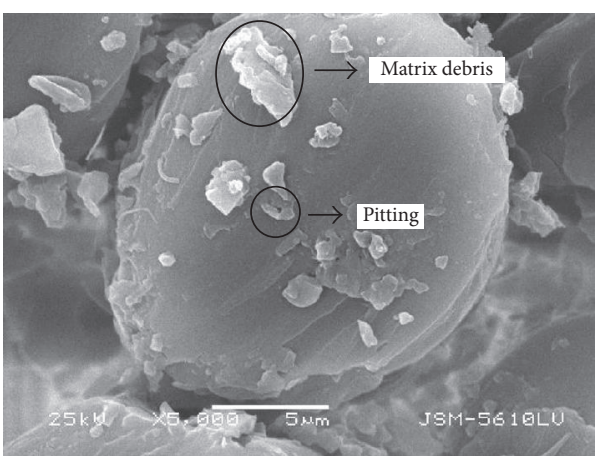

(a) Transverse section $\times 5000$

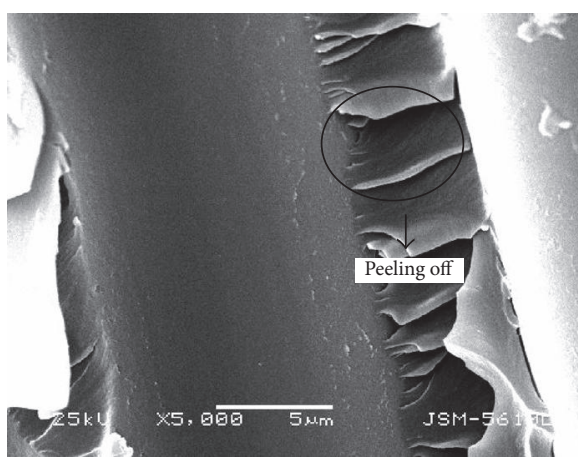

(c) Longitudinal section $\times 5000$

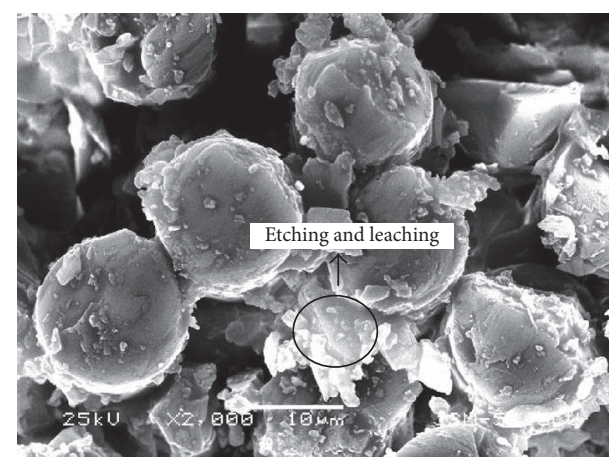

(b) Transverse section $\times 2000$

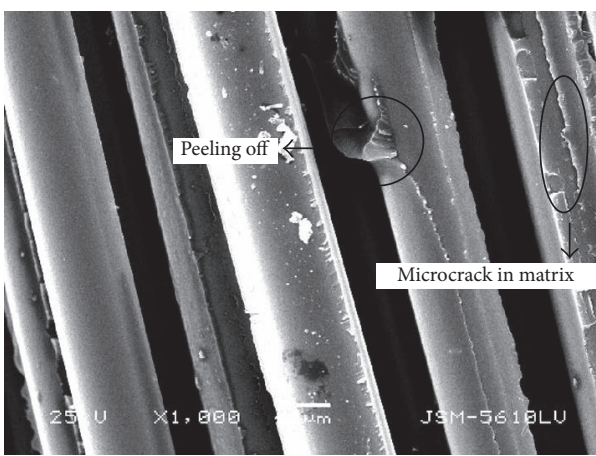

(d) Longitudinal section $\times 1000$

FIgURE 3: Microstructure morphology of GFRP bars embedded in concrete in the standard-curing environment.

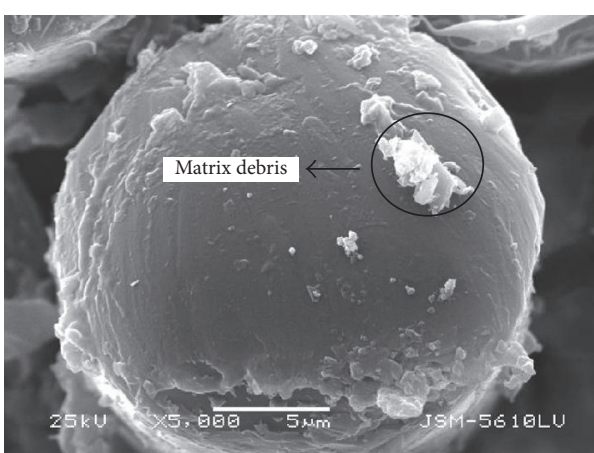

(a) Transverse section $\times 5000$

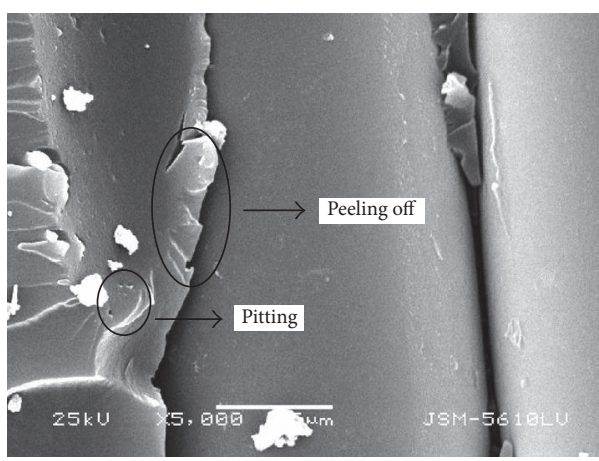

(c) Longitudinal section $\times 5000$

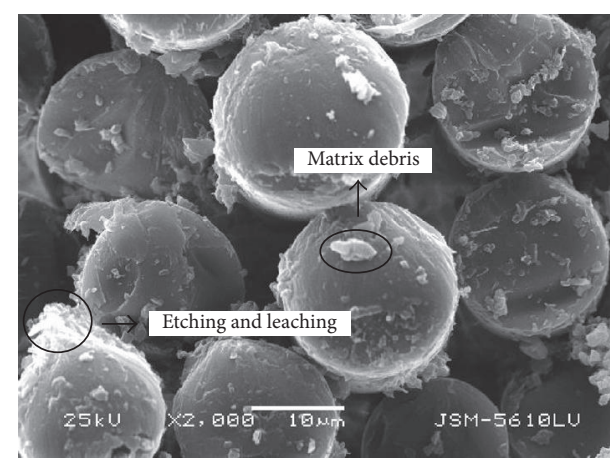

(b) Transverse section $\times 2000$

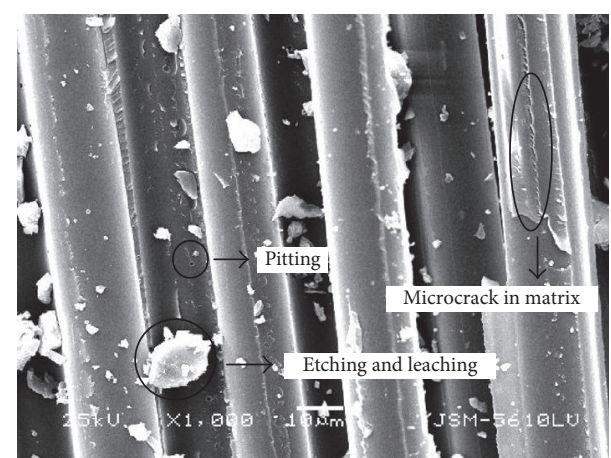

(d) Longitudinal section $\times 1000$

FIGURE 4: Microstructure morphology of GFRP bars in the steam-curing environment. 


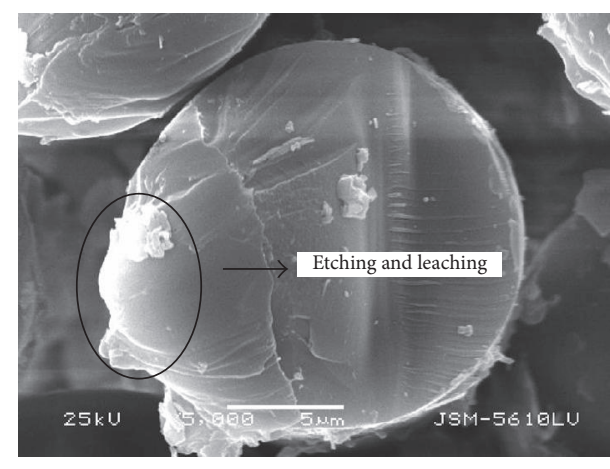

(a) Transverse section $\times 5000$

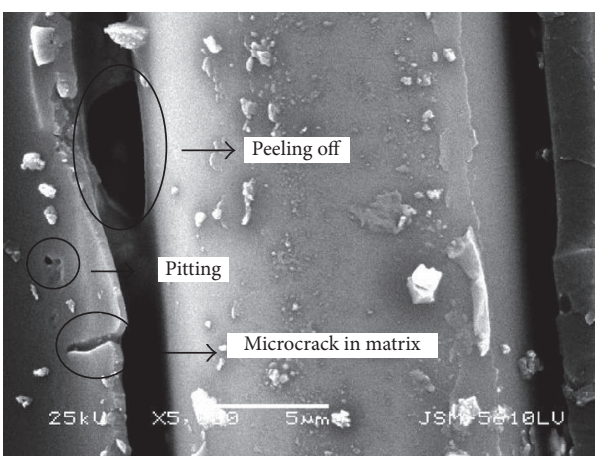

(c) Longitudinal section $\times 5000$

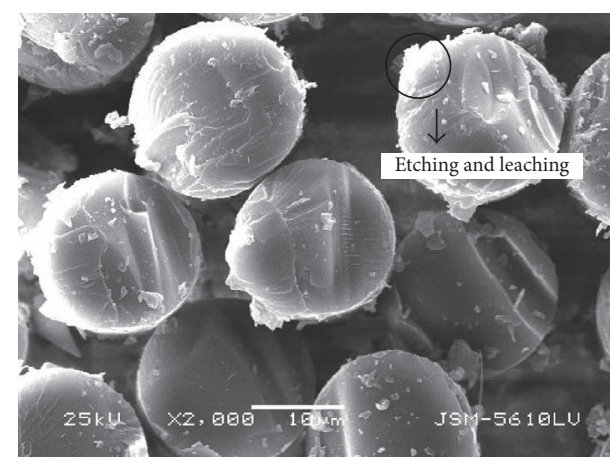

(b) Transverse section $\times 2000$

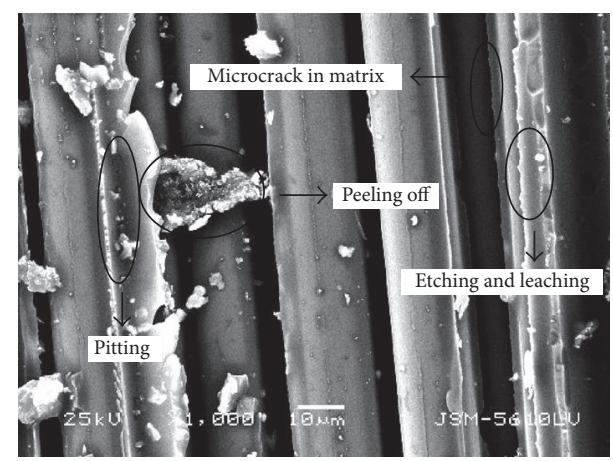

(d) Longitudinal section $\times 1000$

FIGURE 5: Microstructure morphology of GFRP bars embedded in concrete in the steam-curing environment.

TABLE 3: The glass transition temperature of GFRP bars under different curing systems.

\begin{tabular}{lccccc}
\hline Name & Temperature $/{ }^{\circ} \mathrm{C}$ & Duration $/ \mathrm{m}$ & $T_{g}$ run $1 /{ }^{\circ} \mathrm{C}$ & $T_{g}$ run $2 /{ }^{\circ} \mathrm{C}$ & $\mathrm{Cure}$ ratio $/ \%$ \\
\hline $\mathrm{RE}$ & - & - & 123 & 125 & 98.4 \\
$\mathrm{C}-$ Sta & 60 & 9 & 122 & 125 & 97.6 \\
$\mathrm{C}-$ Ste60 & 60 & 9 & 119 & 124 & 96.0 \\
\hline
\end{tabular}

by $0.8 \%$. It is indicated that the irreversible alkaline chemical reactions of the matrix resin have occurred. The glass transition temperature values of C-Ste specimens compared with C-Sta specimens decrease by $0.4 \%$. This result could be explained by the fact that the high temperature curing process accelerated the chemical reaction rate of resin matrix. However, no matter under the standard-curing or steamed-curing concrete environment, no major degradation occurred at the polymer level and that the loss of tensile properties was not related to the degradation of the material.

3.4. Chemical Changes. Figure 6 shows the FTIR analysis of GFRP bars extracted from the standard-curing concrete beams and the steam-curing concrete beams. The curves of the different wavelengths are characterized by different wavelengths. Different vibration frequencies are characteristic of particular types of chemical groups, and the strong absorption band of hydroxyl is located between $3300 \mathrm{~cm}^{-1}$ and $3650 \mathrm{~cm}^{-1}$. It can be seen from Figure 6 that the hydroxyl peak did not reveal any significant changes and the experimental spectra did not show any new characteristic absorption peaks in different curing environment. It indicated that the matrix resins of GFRP bars embedded in standard-curing concrete beams and steam-curing concrete beams did not produce a new group after resin ester bond rupture.

\section{Correlation Analysis on the GFRP Bare Bars and GFRP Bars Embedded in Concrete under Different Curing Systems}

The relationship between the GFRP bare bars and GFRP bars embedded in concrete under different curing systems is established to obtain the tensile properties of GFRP bars embedded in concrete from the data of GFRP bare bars, which greatly reduced the difficulty of GFRP concrete structural design, prediction, and detection.

Table 2 shows that the influence of different curing temperatures on the tensile strength of GFRP bars embedded in concrete is different from the bare bars. When curing temperature is low (below $40^{\circ} \mathrm{C}$ ), the influence of the curing process on bare bars is less than GFRP bars embedded in concrete; the influence on bare bars is greater than GFRP bars embedded in concrete with higher curing temperature 


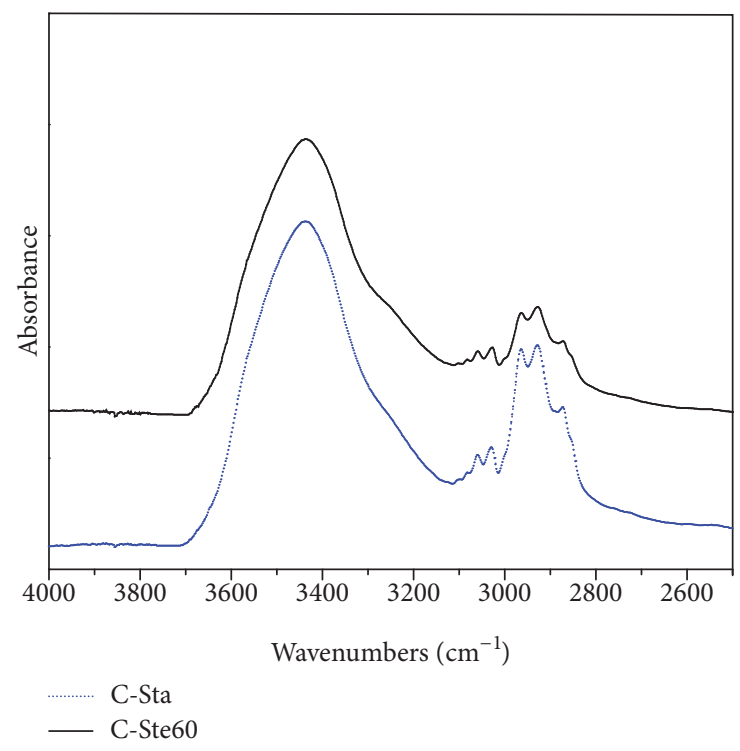

Figure 6: FTIR spectra for C-Sta and C-Ste60 samples.

(higher than $40^{\circ} \mathrm{C}$ ), and the ratio of difference increases with the increase of curing temperature.

Figure 7 shows the relationship between the GFRP bare bars and GFRP bars embedded in concrete which can be expressed by exponential function:

$$
\begin{aligned}
& K_{B}=1.037 \exp (0.033 T), \\
& K_{C}=1.275 \exp (0.025 T),
\end{aligned}
$$

where $K_{B}, K_{C}$ are the attenuation ratio of tensile strength of GFRP bare bars and GFRP bars embedded in concrete and $T$ is curing temperature.

The fitting square difference is 0.97 and 0.99 about the two exponential functions, which can be considered to be in accordance with the actual test results. Therefore, the formula (2)/(1) can be used to express the attenuation ratio relationship of tensile strength between the two methods:

$$
\delta=1.23 \exp (-0.008 T) .
$$

The retention rate of tensile strength of GFRP bars embedded in concrete under different curing systems $\left(Y_{c}\right)$ can be calculated by the attenuation ratio $K_{B}$ and the correlation coefficient $\delta$ :

$$
Y_{C}=100-\delta K_{B}
$$

It indicated that the design tensile strength, fracture reduction coefficient, and bond length determined are needed to fully consider the influence of microstructure and tensile properties of GFRP bars under the curing systems when GFRP bars in concrete component are used in high temperature curing process.

\section{Conclusions}

In this paper, a unique set of experimental data of the GFRP bare bars and the GFRP bars embedded in concrete

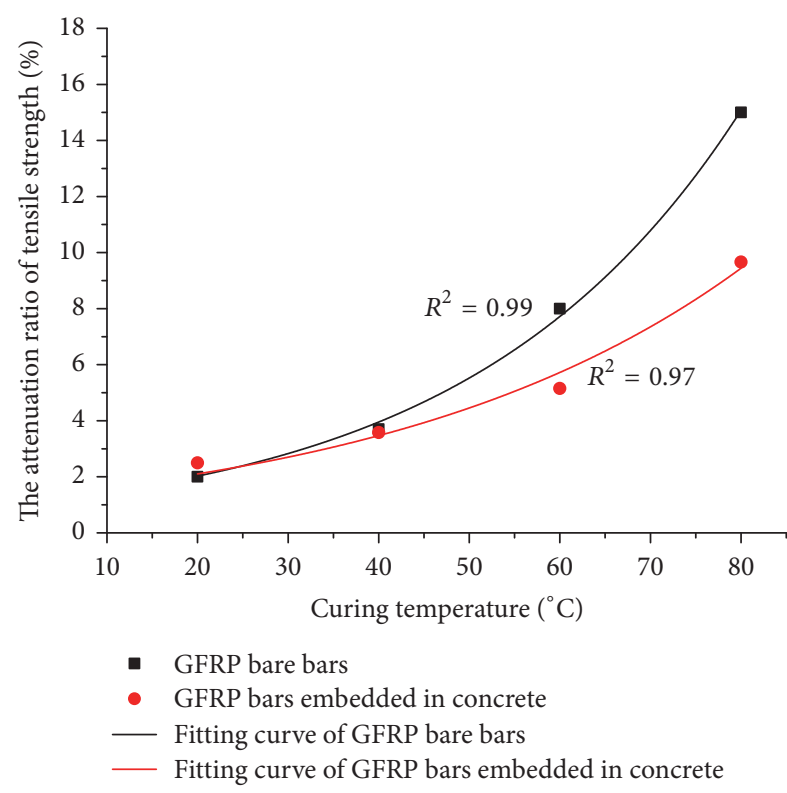

FIGURE 7: The change of tensile strength with curing temperature.

under standard-curing system $\left(20^{\circ} \mathrm{C}\right)$ and steam-curing system $\left(40^{\circ} \mathrm{C}, 60^{\circ} \mathrm{C}\right.$, and $\left.80^{\circ} \mathrm{C}\right)$ was reported to characterize the combined effects of curing temperatures and alkaline concrete on tensile properties of GFRP bars. Based on the results of this study, the following conclusions may be drawn:

(i) The tensile strength of GFRP bars as studied in this work showed that the combined effect of high curing temperature and alkaline concrete on GFRP bars was gradually significant, and the deterioration degree of tensile strength increased with the increase of curing temperature.

(ii) The influence of different curing temperatures on the tensile strength of GFRP bars embedded in concrete was different from the bare bars; when curing temperature was low (below $40^{\circ} \mathrm{C}$ ), the influence on bare bars was less than GFRP bars embedded in concrete; when the curing temperature was high (higher than $40^{\circ} \mathrm{C}$ ), the influence of the curing process of bare bars was greater, and the ratio of difference increased with the increase of curing temperature.

(iii) The microanalysis of GFRP bar was conducted. It was shown that the alkaline concrete environment and the steam-curing temperature of $60^{\circ} \mathrm{C}$ will cause some damage to the GFRP bars, without a significant difference between GFRP bare bars and GFRP bars embedded in concrete under steam-curing system.

(iv) Based on the test data of different curing systems, the exponential correlation equation of two different test methods was established. The attenuation ratio of the tensile strength of GFRP bars embedded in concrete under different curing systems was predicted through the bare test, resulting in reliable results and high $R^{2}$ values. The conclusions of this paper not only can extend previous research results, but also reduce the 
difficulty of the tensile strength test of GFRP bars embedded in concrete.

\section{Competing Interests}

The authors declare that they have no competing interests.

\section{Acknowledgments}

This research was supported by the National Natural Science Foundation of China (Grant no. 51178361).

\section{References}

[1] B. Benmokrane, P. Wang, T. M. Ton-That, H. Rahman, and J.F. Robert, "Durability of glass fiber-reinforced polymer reinforcing bars in concrete environment," Journal of Composites for Construction, vol. 6, no. 3, pp. 143-153, 2002.

[2] Q. Khan, M. Sheikh, and M. Hadi, "Axial-flexural interactions of GFRP-CFFT columns with and without reinforcing GFRP bars," Journal of Composites for Construction, 2016.

[3] Hughes Brothers, Glass Fiber Reinforced Polymer (GFRP) Rebar-Aslan ${ }^{\mathrm{TM}} 100$ Series FIBERGLASS REBAR, Hughes Brothers, Seward, Neb, USA, 2011, http://www.aslanfrp.com.

[4] W. Wang, Experimental and Theoretical Studies on Durability of GFRP Rebars Exposed to Alkaline Environment, Tongji University, 2011, (Chinese).

[5] W. R. Yang, X. J. He, and L. Dai, "Damage behaviour of concrete beams reinforced with GFRP bars," Composite Structures, vol. 161, pp. 173-186, 2017.

[6] X. J. He, J. N. Yang, and C. E. Bakis, “Tensile strength characteristics of GFRP bars in concrete beams with work cracks under sustained loading and severe environments," Journal of Wuhan University of Technology-Materials Science Edition, vol. 28, no. 5, pp. 934-937, 2013.

[7] W. R. Yang, X. J. He, and L. Dai, "Shear performance of GFRP bars embedded in concrete beams with crack in different environments," in Proceedings of the 12th International Symposium on Fiber Reinforced Polymers for Reinforced Concrete Structures (FRPRCS-12 '15), Nanjing, China, December 2015.

[8] W. R. Yang, X. J. He, L. Dai, X. Zhao, and F. Shen, "Fracture performance of GFRP bars embedded in concrete beams with cracks in an alkaline environment," Journal of Composites for Construction, vol. 20, no. 6, Article ID 04016040, 2016.

[9] A. Katz and N. Berman, "Modeling the effect of high temperature on the bond of FRP reinforcing bars to concrete," Cement and Concrete Composites, vol. 22, no. 6, pp. 433-443, 2000.

[10] A. Abbasi and P. J. Hogg, "Temperature and environmental effects on glass fibre rebar: modulus, strength and interfacial bond strength with concrete," Composites Part B: Engineering, vol. 36, no. 5, pp. 394-404, 2005.

[11] K. O. Kjellsen, R. J. Detwiler, and O. E. Gjørv, “Development of microstructures in plain cement pastes hydrated at different temperatures," Cement and Concrete Research, vol. 21, no. 1, pp. 179-189, 1991.

[12] G. M. Campbell and R. J. Detwiler, "Development of mix designs for strength and durability of steam-cured concrete," Concrete International, vol. 15, no. 7, pp. 37-39, 1993.

[13] H. H. Patel, C. H. Bland, and A. B. Poole, "The microstructure of concrete cured at elevated temperatures," Cement and Concrete Research, vol. 25, no. 3, pp. 485-490, 1995.
[14] M.-F. Ba, C.-X. Qian, X.-J. Guo, and X.-Y. Han, "Effects of steam curing on strength and porous structure of concrete with low water/binder ratio," Construction and Building Materials, vol. 25, no. 1, pp. 123-128, 2011.

[15] Z. M. He, Heat Damage Effects of Steam on Concrete and Corresponding Improvement Measures, Central South University, 2012 (Chinese).

[16] C. Sun, W. H. Qiu, X. B. Zeng et al., "Contrast research on mechanical properties experimental of GFRP bars for a long time under different environmental conditions," Fiber Reinforced Plastics/Composites, no. 8, pp. 88-91, 2014 (Chinese).

[17] V. Dejke, Durability of FRP Reinforcement in Concrete, Chalmers University of Technology, Gothenburg, Sweden, 2001.

[18] ACI, "Guide for the design and construction of structural concrete reinforced with fiber-reinforced polymer (FRP) bars," ACI 440.1R-15, American Concrete Institute, Farmington Hills, Mich, USA, 2015.

[19] JGJ55-2011, Concrete Mix Design Procedures, China Building Industry Press, Beijing, China, 2011.

[20] China Building Industry Press, "Ordinary concrete mechanics performance test method standard," Tech. Rep. GB/T500812002, China Building Industry Press, 2003.

[21] TB10752-2010, High Speed Railway Bridge Engineering Construction Quality Acceptance Standards, China Railway Press, Beijing, China, 2011.

[22] ACI 440.3R-04, Guide Test Methods for Fiber-Reinforced Polymers (FRPs) for Reinforcing or Strengthening Concrete Structures, American Concrete Institute Farmington Hills, Farmington Hills, Mich, USA, 2004.

[23] J. M. Sousa, J. R. Correia, S. Cabral-Fonseca, and A. C. Diogo, "Effects of thermal cycles on the mechanical response of pultruded GFRP profiles used in civil engineering applications," Composite Structures, vol. 116, no. 1, pp. 720-731, 2014.

[24] M. Robert and B. Benmokrane, "Combined effects of saline solution and moist concrete on long-term durability of GFRP reinforcing bars," Construction and Building Materials, vol. 38, no. 1, pp. 274-284, 2013.

[25] A. Mufti, M. Onofrei, B. Benmokrane et al., "Durability of GFRP reinforced concrete in field structures," ACl Stucture Journal, vol. 230, pp. 1361-1378, 2005. 

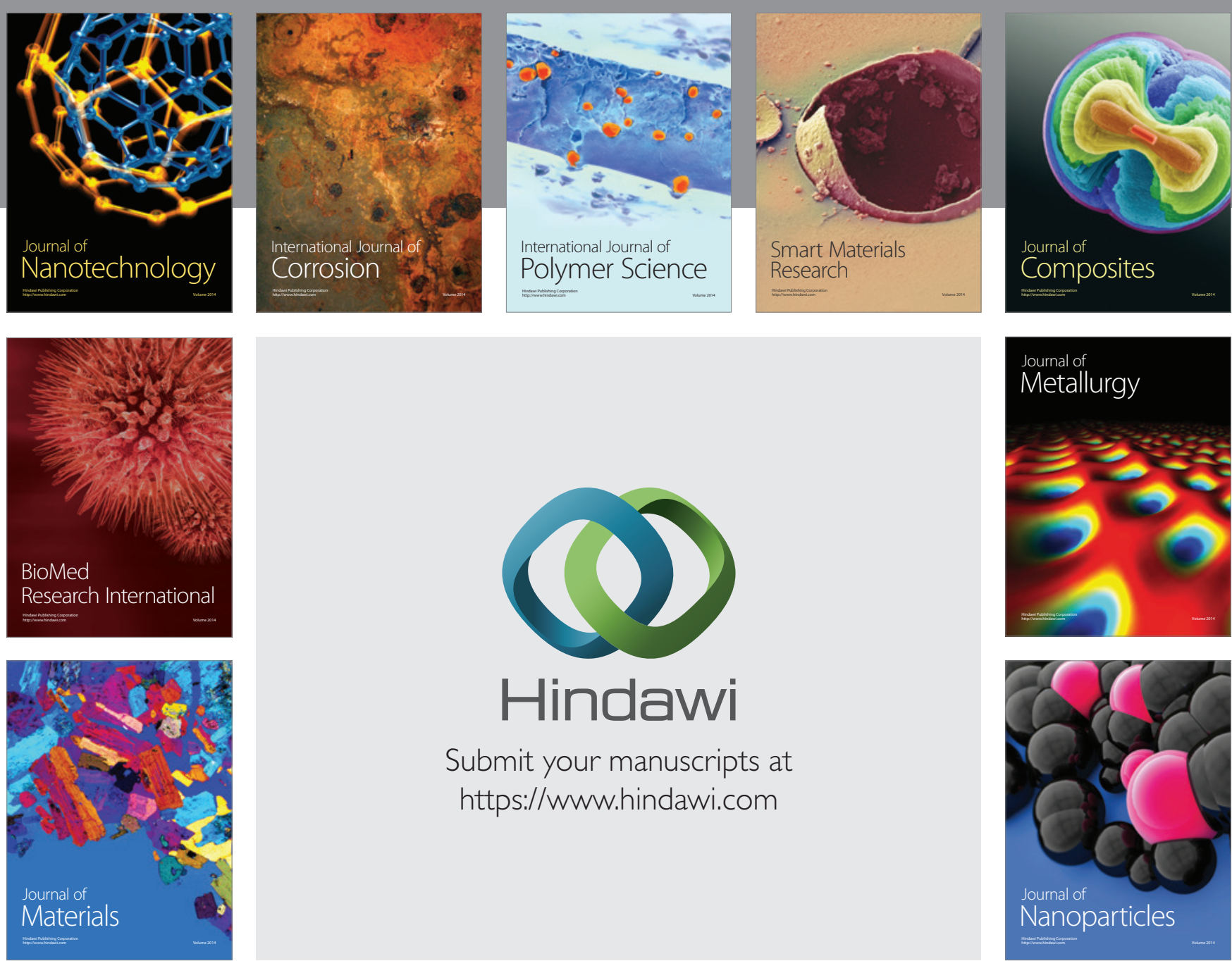

\section{Hindawi}

Submit your manuscripts at

https://www.hindawi.com

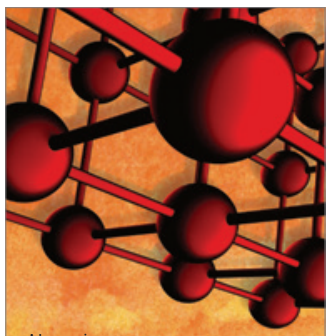

Materials Science and Engineering
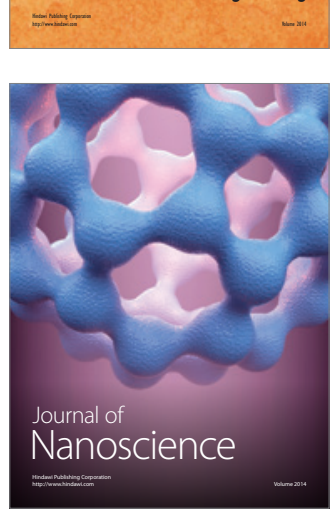
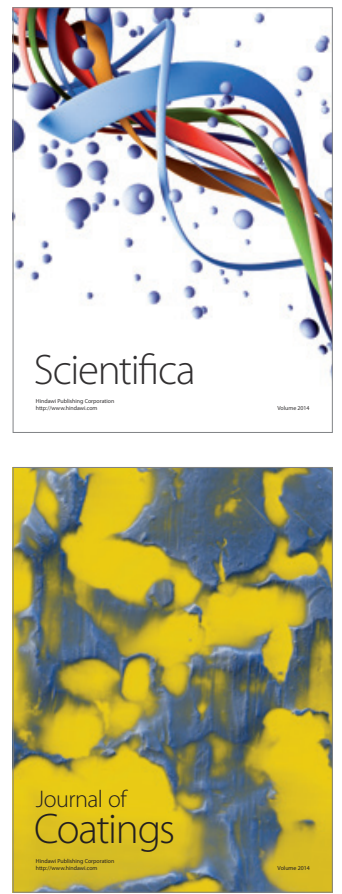
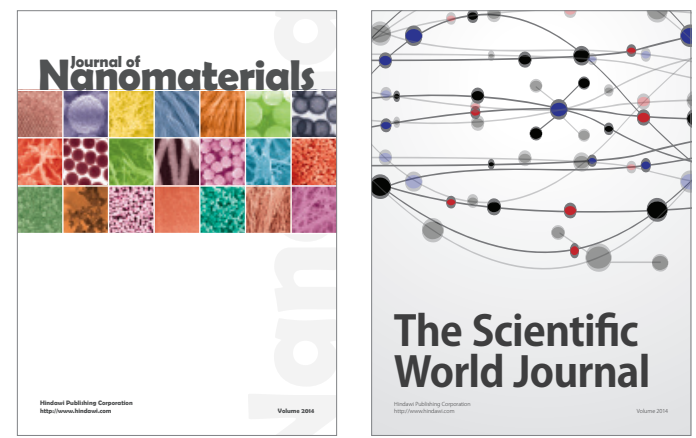

The Scientific World Journal
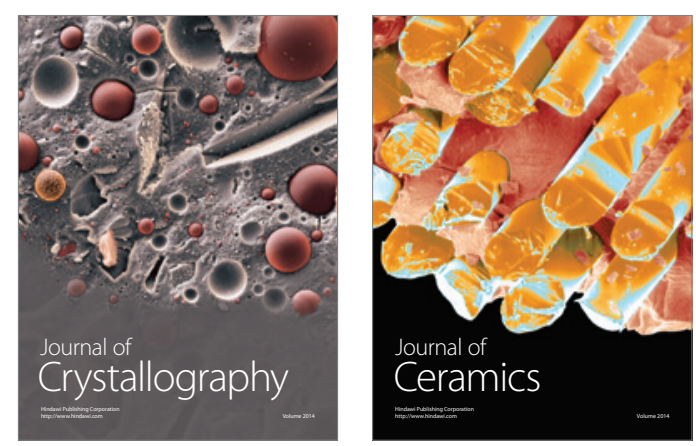
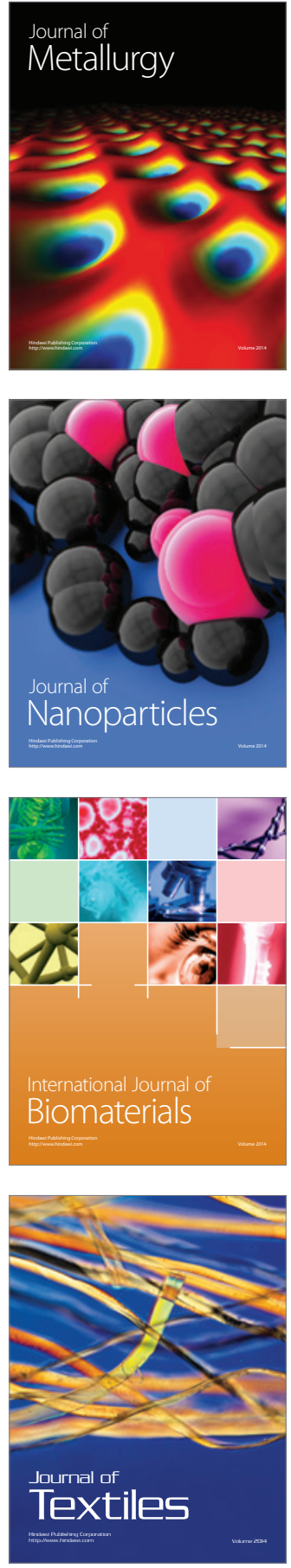